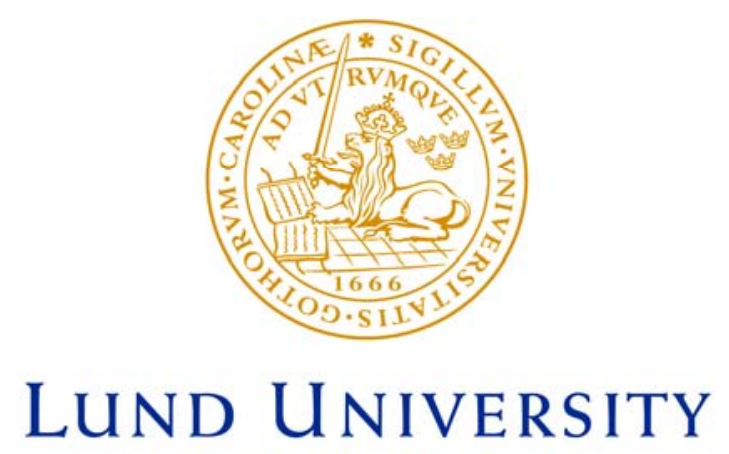

Faculty of Medicine

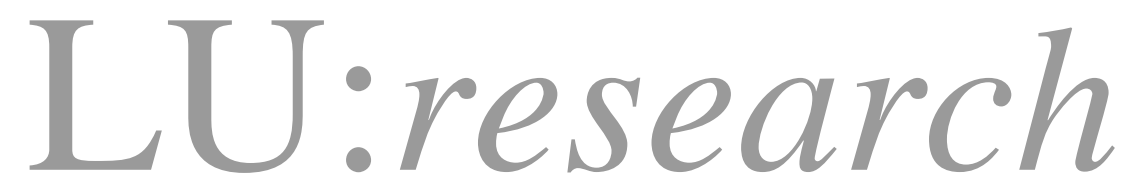

Institutional Repository of Lund University

This is an author produced version of a paper published in Advances in health economics and health services research. This paper has been peer-reviewed but does not include the final publisher proof-corrections or journal pagination.

Citation for the published paper:

Traskman-Bendz, Lil and Westling, Sofie.

"The psychobiology of aggressive behaviour."

Adv Health Econ Health Serv Res, 2007, Vol: 16, pp. 3-14.

Access to the published version may

require journal subscription.

Published with permission from: Elsevier 


\title{
The psychobiology of aggressive behaviour
}

\author{
Lil Träskman-Bendz, MD PhD and Sofie Westling, MD, \\ Dept Clinical Neurosciences, Lund University, Sweden
}

\section{Introduction.}

Aggressive behaviour is one of many mammal instincts for survival. Among humans, advanced psychological functions contribute to several expressions of aggression. One example is suicidal aggression. There are reports on murderers who later committed suicide, or on patients with severe psychiatric illness, who committed extended suicide. About $25 \%$ of violent psychiatric patients have harmed themselves, while about $10 \%$ of suicide attempters have a history of assault (Plutchik \& Van Praag, 1989). These researchers also reported a high correlation between ratings of suicide risk and ratings of violence. Furthermore, Engström et al (1999) found temperamental similarities between suicide attempters and violent offenders.

Swedish studies show a high premature mortality in criminal populations. Lidberg (1993) reported that violent deaths were common among delinquents, and about $50 \%$ of these deaths were suicides.

According to Gray (1987) and Barrat (1991), hostility and anxiety are signs of brain arousal, and individuals with high arousal are sensitive to external stressful events. Their psychic tension disappears only after a destructive break through. Another aspect of aggression is an inherent inability to control impulses. Schalling (1993) suggested impulsivity to be the link between psychopathology and biological vulnerability, as similar, or even the same, biological deviations could be seen in impulsive, self-destructive and antisocial persons. Impulsive and aggressive traits might contribute significantly to the risk of attempting suicide among alcoholics (Koller et al, 2002).

Male alcoholic individuals could be classified into type I alcoholics (late onset) or type II (early onset with antisocial traits) according to criteria described by Cloninger (1987). Finnish alcoholic, impulsive offenders have personality profiles like type II alcoholics (Virkkunen \& Linnoila, 1993). According to Cloninger (1987), type II alcoholics have high family loading, less ability to abstain from alcohol, little guilt or fear associated with drinking, and more frequent alcohol-related antisocial behaviour.

Mulder (2001) performed a cross-sectional review on alcoholism and personality and concluded that there is a clear association between antisocial behaviour and alcoholism, and antisocial behaviour seems to start before alcoholism. Childhood conduct disorder and hyperactivity have also been mentioned as factors predisposing alcoholism and antisocial behaviour (Söderström, 2002). Interestingly, this typology of childhood risk-factors is not specific for alcoholism, as it is generally accepted in psychiatry that early onset of disorders means that they are most probably genetically determined, and that their life course becomes increasingly severe and complicated (Mulder et al, 1994)

Neurobiological aspects of aggressive behaviour.

Brain regions of importance for aggression are e.g. the sensory cortical areas, amygdala, hippocampi, hypothalamus, brain stem, prefrontal cortex and corpus callosum. The site of action determines the impact of various functions (Table). The regulatory monoaminergic systems play an important role in this organization. 


\section{Monoamines (Fig. 1).}

There is a well known association between aggressive behaviour and low function of the monoamine serotonin (Valzelli, 1981). Depue and Spoont (1986) concluded that there are two behavioural systems, one inhibiting and one facilitating. The former is sensitive to environmental stimuli and is linked with serotonergic pathways in the septum-hippocampus area. The latter is activated during goal-oriented behaviour and is linked with the mesolimbic dopamine paths. This two system model, in which dopamine and serotonin modulate each other, might explain personality features such as impulsivity and mood fluctuations. Levels of the serotonin metabolite 5-hydroxyindoleacetic acid (5-HIAA), analysed in lumbar cerebrospinal fluid (CSF), are often low in patients who make violent suicide attempts, as well as in impulsive violent offenders, impulsive arsonists, and people with a history of aggressive acts. (Åsberg et al, 1976; Träskman et al, 1981; Virkkunen et al, 1987; Lidberg et al, 1985; Brown et al, 1979). Ågren and coworkers (1986) suggested low CSF levels of both serotonin- and dopamine - metabolites among impulsive violent or suicidal individuals. Söderström et al (2003) reported a strong association of the CSF HVA 5-HIAA ratio with psychopathic traits.

In alcoholic criminal offenders, low CSF 5-HIAA was associated with irritability and impaired impulse control (Virkkunen et al, 1994).

Platelets could be regarded as neuron- models. Activity of the degradating enzyme monoamine oxidase ( MAO) in platelets might be used for subtyping alcoholics (Demir et al, 2002). There are many studies which show low platelet MAO-activity in impulsive and/or sensation seeking persons, individuals with type 2 (early onset) alcoholism, and in recurrent criminality (Lidberg et al, 1985; Buchsbaum et al, 1976; Oreland et al 2002). Suicidal impulsive patients with alcoholism had low platelet MAO activity according to our studies (Engström et al, 1996). Psychotic violent offenders had lower platelet MAO-activity than other criminal persons according to another study (Belfrage et al, 1992).

Deviances in serotonin receptor function, or abnormal binding to platelet-membrane receptors, or receptor-binding in Single Photon Emission Computerized Tomography (SPECT) studies of the brain, have also been reported in depressed suicidal, violent and/or impulsive patients with or without alcoholism (Simonsson et al, 1991; Pandey et al, 2002; Tiihonen et al, 1997; Lindström et al, 2004; Audeanuert et al, 2001; Heinz et al, 2001).

Blunted responses after serotonin-challenge reflect decreased serotonin function in the limbic system and hypothalamus. Associations between such blunted responses and impulsivity, irritability, aggression, suicidal behaviour and antisocial behaviour have been reported by several researchers (Coccaro et al, 1990; Manuck et al,. 2002). Similarly, Fishbein et al (1989) reported blunted reactions in impulsive and aggressive substance users. Low serotonin function was also seen in children with a familial type of aggression (Halperin et al, 2003). Gerra et al (2004) observed impaired serotonin function in heroin addicts, which in combination with certain temperamental traits, could increase the proneness for addiction, and probably complicated clinical pictures, e.g. comorbidity, as well.

King (1986) reviewed the role of catecholamines for aggressiveness, and reported that several studies showed that mesolimbic dopamine causes an impairment of the behavioural responsethreshold, which in turn results in increased aggression. 


\section{Neuroactive steroids (Fig.2).}

Higley et al (1992) studied aggressive rhesus monkeys and found low CSF 5-HIAA and high CSF noradrenaline as well as high levels of corticotrophin (ACTH) and cortisol in plasma. This indicates that these monkeys not only were aggressive (serotonin) but also had a high arousal (noradrenaline and steroids).

Deviances in steroid metabolism have been proven in relation to both suicidal and violent behaviour. High corticosteroid concentrations as well as nonsuppression of cortisol in the dexamethasone suppression test have been observed in depressed suicidal patients (Coryell \& Schlesser, 2001). In contrast, suicidal individuals with impulsive personality disorders have low $24 \mathrm{~h}$ urinary and plasma concentrations (Westrin et al, 2003).

High serum testosterone was seen in male delinquents of different ages (Mattsson et al, 1980; Rasanen et al, 1999). In violent and alcoholic offenders, high free CSF testosterone was associated with aggressiveness, monotony avoidance, sensation seeking, suspiciousness and reduced socialization (Virkkunen et al, 1994). These findings are in contrast to results reported by Gustavsson et al (2003), where depressed males had significantly lower CSF testosterone than others. CSF 5-HIAA did not correlate significantly with CSF testosterone in this study. The reason for this is probably that 5-HIAA is related to impulsivity rather than to aggressiveness (Linnoila et al, 1983; Virkkunen \& Linnoila, 1993).

At present, there are interesting discussions concerning the possible role of low cholesterol in violent behaviour. Originally, epidemiological investigations found an association between low cholesterol and violent death in the county of Värmland, Sweden (Lindberg et al, 1992). Later, studies on suicidal patients and aggressive primates have shown relationships between low serotonergic function and low cholesterol, which probably could be explained by disrupted cellular membranes due to shortage of cholesterol, and hence receptors becoming increasingly weak or sensitive (Scanlon et al, 2001). Golomb et al (2000) reported low cholesterol in violent criminals. A recent study by Repo-Tiihonen et al (2002) showed that low levels of another lipid, triglyceride, were associated with childhood onset of conduct disorder and premature death.

\section{Carbohydrates.}

Low blood-glucose has been noticed in aggressive individuals, probably due to high insulin levels. (Linnoila et al, 1989; Virkkunen et al, 1994). In our group, Westling et al (2004) have shown high CSF insulin in patients who made violent suicide attempts, and this was regardless of psychiatric diagnosis.

In one study of alcoholics, a 5-hour oral glucose tolerance test, in which glucose, prolactin and cortisol responses were measured, was performed by Fishbein et al (1992). Low nadir cortisol and blunted prolactin response to glucose were linked with antisocial personality and aggressiveness.

Virkkunen et al (1994) reported that type 2 alcoholics were vulnerable to hypoglycemic reactions after an oral load of glucose.

\section{Genes and the family}

Delinquent behaviour can be seen across generations. Long-term studies have shown that conduct disorder during childhood may predispose school-problems, deviant peers, antisocial criminal adult behaviour and/or alcoholism (Olweus, 1978). Much of this effect is genetically determined (Heath et al, 1997). When healthy individuals, who had alcoholic fathers, were subject to stress tests with and without alcohol, it was found that alcohol given to these 
subjects attenuated the stress-response, which was not the case concerning subjects without alcoholic fathers (Zimmerman et al, 2004)

Recent investigations reveal that a functional polymorphism in the gene coding for MAO A (high MAOA expression) could moderate the effect of maltreatment during childhood (Caspi et al, 2002).

Genetic factors are supposed to contribute to about $40 \%$ of personality variance.

Among monoaminergic genes, MAOA gene polymorphisms, e.g. the low activity 3-repeat allele, confer increased susceptibility of antisocial and aggressive behaviour (Samochowiec et al, 1999; Manuck et al, 2002). Behavioural deviances often seen in people with low platelet MAO-B activity, could be explained by the presence of two long alleles of the transcription factor AP-2 beta gene (Oreland et al, 2002).

Serotonin transporter genes have also been studied in various populations, and the 5HTTLPR polymorphism might contribute to early onset alcoholism and violent behaviour rather than to suicidal behaviour (Hallikainen et al, 1999; Zalsman et al, 2001).

According to Manuck et al (1999), an aggressive disposition is associated with an intronic polymorphism of the tryptophan hydroxylase (TPH) gene

\section{Conclusion.}

So far, psychobiological research suggests that monoaminergic genes, childhood conduct disorder as well as environmental stress predispose deviant behaviour such as antisocial aggressive behaviour or type II alcoholism later in life. Excitatory and inhibitory biochemical and psychosocial powers are constantly acting in consert. Apart from monoamines, steroids and carbohydrates are involved in aggression and violence. Current research using brainimaging techniques will certainly offer further understanding of biological events and hopefully a chance to invent specific treatment tools for this behaviour, socio-economically deleterious for the individual, his/her immediate surroundings, and society at large.

Acknowledgements.

Our studies are supported by the Swedish Research Council, the Sjöbring Foundation, the Skåne County research foundation and the Lund University ALF (government funds to support the research of medical doctors). Ulla Persson is greatly acknowledged.

\section{References.}

Ågren H, Mefford IN, Rudorfer MV, et al. Interacting neurotransmitter systems. A nonexperimental approach to the 5HIAA-HVA correlation in human CSF. J Psychiatr Res 1986;20:175-193.

Åsberg M, Träskman L, Thorén P. 5-HIAA in the cerebrospinal fluid - a biochemical suicide predictor? Arch Gen Psychiatry 1976;33:1193-1197.

Audenaert K, Van Laere K, Dumont F et al. Decreased frontal serotonin 5-HT 2a receptor binding index in deliberate self-harm patients. Eur J Nucl Med 2001;28:175-182.

Barrat ES. Measuring and predicting aggression within the context of personality theory. $\mathrm{J}$ Neuropsychiatry Clin Neurosci 1991;3(suppl 1):35-39.

Belfrage H, Lidberg L, Oreland L. Platelet monoamine oxidase activity in mentally disordered violent offenders. Acta Psychiatr Scand 1992;85:1-4.

Brown GL, Goodwin FK, Ballenger JC, et al. Aggression in humans correlates with cerebrospinal fluid amine metabolites. Psychiatry Res 1979;1:131-139.

Buchsbaum MS, Coursey RD, Murphy DL. The biochemical high-risk paradigm: behavioural and familial correlates of low platelet monoamine oxidase activity. Science 1976; 194:339-341.

Caspi A, McClay J, Moffitt TE et al. Role of Genotype in the cycle of violence in maltreated 
children. Science 2002; 297: 851-854.

Cloninger CR. Neurogenetic adaptive mechanisms in alcoholism. Science 1987; 236: 410416.

Cloninger CR, Sigvardsson S, Bohman M. Childhood personality predicts alcohol abuse in young adults. Alcoholism: Clinical and Experimental Research 1988; 12:494-505.

Coccaro EF, Gabriel S, Siever LJ. Buspirone challenge: preliminary evidence for a role for central 5-HT 1A receptor function in impulsive aggressive behaviour. Psychopharm Bull 1990; 3: 393-405.

Coryell W, Schlesser M. The dexamethasone suppression test and suicide prediction. Am J Psychiatry 2001; 158: 748-753.

Demir B, Ucar G, Ulug B et al. Platelet monoamine oxidase activity in alcoholism subtypes: relationship to personality traits and executive functions. Alcohol Alcohol 2002; 37(6): 597-602.

Depue RA, Spoont MR. Conceptualizing a serotonin trait. A behavioural dimension constraint. Ann N Y Acad Sci.1986;487:47-62.

Engström G, Persson B, Levander S. Temperament traits in male suicide attempters and violent offenders. Eur Psychiatry 1999; 14(5): 278-83.

Engström G, Nyman GE, Träskman-Bendz L. The Marke-Nyman Temperament (MNT) Scale in suicide attempters. Acta Psychiatr Scand 1996;94:320-325.

Fishbein DH, Dax E, Lozovsky DB et al. Neuroendocrine responses to a glucose challenge in substance users with high and low levels of aggression, impulsivity, and antisocial personality. Neuropsychobiology 1992; 25(2): 106-114.

Fishbein DH, Lozovsky D, Jaffe JH. Impulsivity, aggression, and neuroendocrine responses to serotonergic stimulation in substance abusers. Biol Psychiatry 1989; 25(8): 10491066.

Gerra G, Garofano L, Bosari S et al. Analysis of monoamine oxidase A (MAO-A) promoter polymorphism in male heroin-dependent subjects: behavioural and personality correlates. J Neural Transm. 2004; 111(5): 611-621.

Golomb BA, Stattin H, Mednick S. Low cholesterol and violent crime. J Psychiatr Res 2000; 34 (4-5): 301-309.

Gray JA. The psychology of fear and stress. New Yor: Cambridge University Press, 1987.

Gustavsson G, Träskman-Bendz L, Westrin Å. CSF testosterone in 43 male suicide attempters. Eur Neuropsychopharmacol 2003; 13:105-109.

Hallikainen T, Saito T, Lachman HM et al. Association between low activity serotonin transporter promoter genotype and early onset alcoholism with habitual impulsive violent behavior. Mol Psychiatry 1999; 4(4): 385-388.

Halperin JM, Schulz KP, McKay KE et al. Familial correlates of central serotonin function in children with disruptive behavior disorders. Psychiatry Res 2003; 119 (3): 205-216.

Heath AC, Bucholz KK, Madden PA et al. Genetic and environmental contributions to alcohol dependence risk in a national twin sample: consistency of findings in women and men. Psychological Medicine 1997; 27: 1381-1396.

Heinz A, Mann K, Weinberger DR et al. Serotonergic dysfunction, negative mood states, and response to alcohol. Alchol Clin Exp Res 2001;25:485-486.

Higley JD, Mehlman PT, Taub DM et al. Cerebrospinal fluid monoamine and adrenal correlates of aggression in free-ranging rhesus monkeys. Arch Gen Psychiatry 1992; 49: 436-441.

King RB. Neuropharmacology of depression, anxiety and pain. Clin Neurosurg 1981;28:116136.

Koller G, Preuss UW, Bottlender M et al. Impulsivity and aggression as predictors of suicide attempts in alcoholics. Eur Arch Psychiatry Clin Neurosci 2002; 252 (4): 144 - 160. 
Lidberg L, Modin I, Oreland L et al. Platelet monoamine oxidase activity and psychopathy. Psychiat Res 1985; 16: 339-343.

Lidberg L. Criminality - a fatal disease? Läkartidningen 1993; 90: 918,923.

Lidberg L, Tuck JR, Asberg M, et al. Homicide, suicide and CSF 5-HIAA.Acta Psychiatr. Scand 1985; 71:230-236.

Lindberg G, Rastam L, Gullberg B, et al. Low serum cholesterol concentration and short term mortality from injuries in men and women. BMJ 1992;305:277-29.

Lindstrom MB, Ryding E, Bosson P, et al. Impulsivity related to brain serotonin transporter binding capacity in suicide attempters. Eur Neuropsychopharmacol 2004;14:295-300.

Linnoila M, Virkkunen M, Scheinin M, et al. Low cerebrospinal fluid 5-hydroxyindoleacetic acid concentration differentiates impulsive from nonimpulsive violent behavior., Life Sci 1983;33:2609-2614.

Linnoila M, DeJong J, Virkkunen M. Monoamines, glucose metabolism and impulse control. Psychopharmacol Bull 1989;25:404-406.

Manuck SB, Flory JD, Muldoon MF et al. Central nervous system serotonergic responsivity and aggressive disposition in men. Psychol Behav 2002; 77(4-5): 705 - 709.

Manuck SB, Flory JD, Ferrell RE et al. Aggression and anger-related traits associated with a polymorphism of the tryptophan hydroxylase gene. Biol Psychiatry 1999; 45(5): $603-$ 614.

Mattsson A, Schalling D, Olweus D et al. Plasma testosterone, aggressive behavior, and personality dimensions in young male delinquents.J Am Acad Child Psychiatry 1980; 19:476 - 490 .

Mulder RT, Wells JE, Joyce PR, et al. Antisocial women. Journal of Personality Disorders 1994;8:279-287.

Mulder RT. Alcoholism and personality. Australian and New Zealand J of Psychiatry 2001; 36:44-52.

Olweus D. The consistency issue in personality psychology revisted - with special reference to aggression. Br J Soc Clin Psychol 1980; 19: 377-390.

Oreland L, Damberg M, Hallman J et al. Risk factors for the neurohumoral alterations underlying personality disturbances. Neurotox Res 2002; 4(5-6): 421-426.

Pandey GN, Dwivedi Y, Rizavi HS et al. Higher expression of serotonin 5-HT(2A) receptors in the post-mortem brains of teenage suicide victims. Am J Psychiatry 2002; 159:419-429.

Plutchik R, Van Praag HM. The measurement of suicidality, aggressivity and impulsivity. Progr Neuro-Psychopharmacol \& Biol Psychiat 1989; 13: 23-34.

Rasanen P, Hakko H, Visure S, et al. Serum testosterone levels, mental disorders and criminal behaviour. Acta Psychiatr Scand 1999; 99:348-352.

Repo-Tiihonen E, Halonen P, Tiihonen J et al. Total serum cholesterol level, violent criminal offences, suicidal behavior, mortality and the appearance of conduct disorder in Finnish male criminal offenders with antisocial personality disorder. Eur Arch psychiatry Clin Neurosci 2002; 252 (1): 8-11.

Samochowiec J, Lesch KP, Rottmann M et al. Association of a regulatory polymorphism in the promoter region of the monoamine oxidase A gene with antisocial alcoholism. Psychiatry Res 1999; 86 (1): 67-72.

Scanlon SM, Williams DC, Schloss P. Membrane cholesterol modulates serotonin transporter activity. Biochemistry 2001;40(35):10507-10513.

Schalling D. Neurochemical correlates of personality, impulsivity, and disinhibitory suicidality. In Hodgins S (ed) Mental disorder and crime. New York, NY: Sage Publications, 1993:208-226.

Simonsson P, Träskman-Bendz L, Alling C et al. Peripheral markers in patients with suicidal 
behavior. Eur Neuropsychopharmacology 1991;1:503-510.

Söderström H, Blennow K, Sjödin A-K et al. New evidence for an association between the CSF HVA:5-HIAA ratio and psychopathic traits. J Neurol Neurosurg Psychiatry 2003; 74: 918-921.

Söderström H. Neuropsychiatric background factors to violent crime. Göteborg dissertations: Kompendiet, 2002.

Tiihonen J, Kuikka JT, Bergstrom KA, et al. Single-photon emission tomography imaging of monoamine transporter in impulsive violent behaviour. Eur J Nucl Med 1997; 24: 1253-1260.

Träskman L, Åsberg M, Bertilsson L, et al. Monoamine metabolites in cerebrospinal fluid and suicidal behaviour. Arch Gen Psychiatry 1981;38:631-642.

Valzelli L. Psychopharmacology of aggression: an overview. Int Pharmacopsychiatry 1981; 16:39-48.

Virkkunen M, Rawlings R, Tokola R, et al. CSF biochemistries, glucose metabolism, and diurnal activity rhythms in alcoholic, violent offenders, fire setters, and healthy volunteers. Arch Gen Psychiatry 1994;51:20-27.

Virkkunen M, Kallio E, Rawlings R et al. Personality profiles and state aggressiveness in Finnish alcoholic, violent offenders, fire setters, and healthy volunteers. Arch Gen Psychiatry 1994; 51(1): 28-33.

Virkkunen M, Linnoila M. Brain serotonin, type II alcoholism and impulsive violence. J Stud Alcohol 1993; (Suppl) 11:163-169.

Virkkunen M, Nuutila, Goodwin FK et al. Cerebrospinal fluid monoamine metabolite levels in male arsonists. Arch Gen Psychiatry 1987;44:241-247.

Westling S, Ahrén B, Träskman-Bendz L, et al. High CSF-insulin in violent suicide Attempters. Psychiatry Research 2004; 129: 249-255.

Westrin Å, Frii K, Träskman-Bendz L. The dexamethasone suppression test and DSM-III-R diagnoses in suicide attempters. Eur Psychiatry 2003; 18:350-355.

Zalsman G, Frisch A, Bromberg M et al. Family-based association study of serotonin transporter promoter in suicidal adolescents: no association with suicidality but possible role in violence traits. Am J Med Genet. 2001; 105 (3): 239-245.

Zimmerman U, Spring K, Wittchen HU et al. Arginine vasopressin and adrenocorticotropin secretion in response to psychosocial stress is attenuated by ethanol in sons of alcohol-dependent fathers. J Psychiatr Res 2004; 38(4): 385-393. 
Table. The role of different brain regions for aggressive behaviour

\begin{tabular}{|l|l|}
\hline Brain region & Main function related to aggression \\
\hline Sensory cortical areas & Input becomes conscious \\
\hline Amygdala & $\begin{array}{l}\text { Colouring of input by memories, emotions, } \\
\text { and urges from the limbic system }\end{array}$ \\
\hline Hippocampi & Associative learning \\
\hline Hypothalamus & Connects to autonomic input and output \\
\hline Brain stem & Stereotyped responses to emotions and urges \\
\hline Prefrontal cortex & $\begin{array}{l}\text { Executive functions such as planning, } \\
\text { impulse control, and strategies }\end{array}$ \\
\hline Corpus callosum & $\begin{array}{l}\text { Connections between the dominant, } \\
\text { language-steering hemisphere and the } \\
\text { subordinate hemisphere responsible for } \\
\text { interpretation of emotions an non-verbal } \\
\text { information }\end{array}$ \\
\hline
\end{tabular}

(From Söderström, 2002) 
Figure 1. Monoamines are degradated by use of the enzyme monoamine oxidase (MAO) to 5-hydroxyindoleacetic acid (5-HIAA), homovanillic acid (HVA), and 3-methoxy- 4-hydroxyphenyl glycol (MHPG), which are found in the brain as well as in the rest of the body.

\section{Monoamines and metabolites}

Serotonin

5-HIAA

MAO

Dopamine

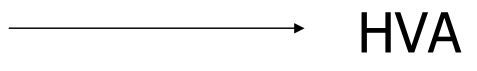

MAO

Noradrenaline

MHPG

MAO 
Figure 2. Parts of steroid metabolism of relevance for aggressive behaviour.

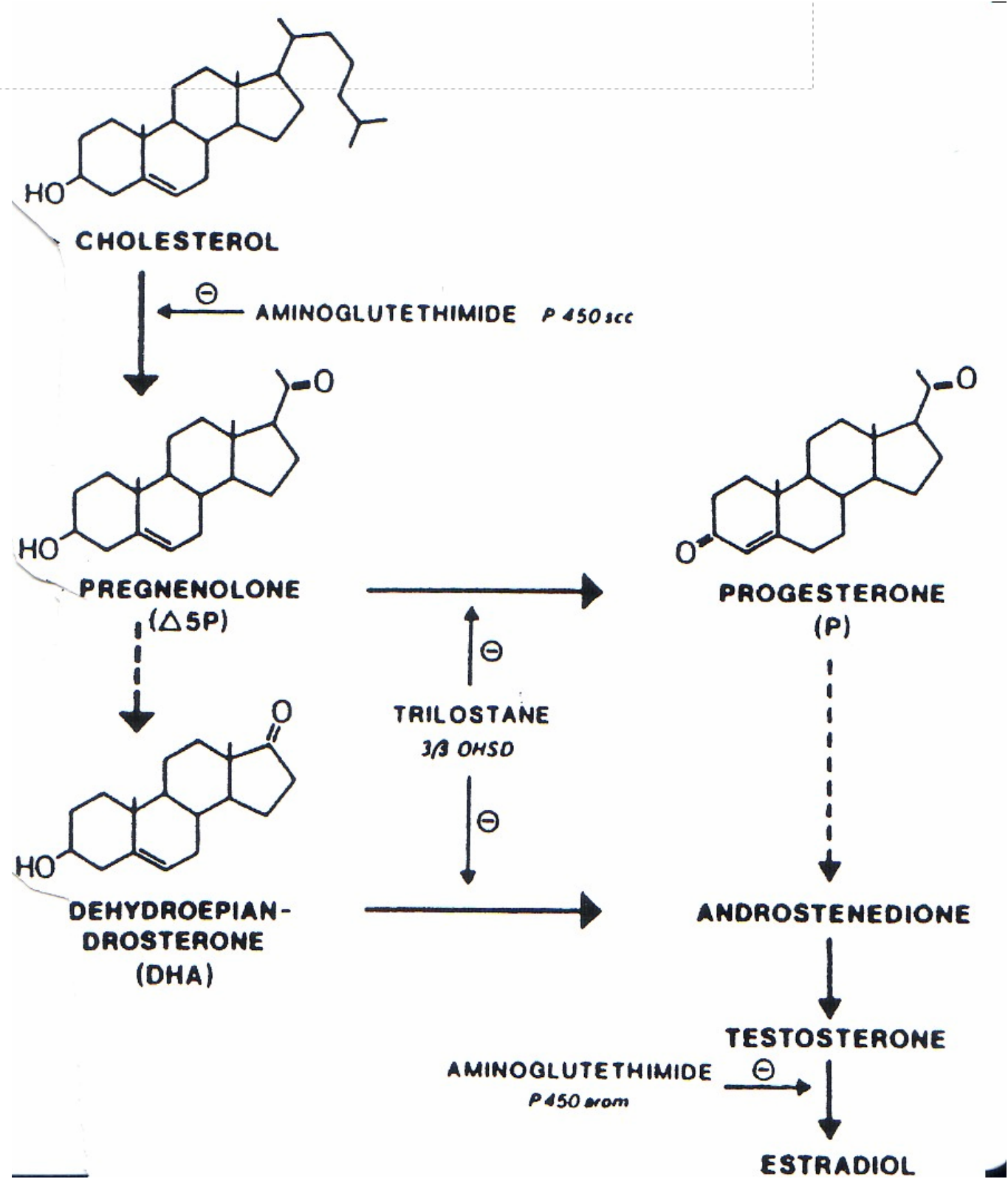

